\title{
SLAMF7 wt Allele
}

National Cancer Institute

\section{Source}

National Cancer Institute. SLAMF7 wt Allele. NCI Thesaurus. Code C95307.

Human SLAMF7 wild-type allele is located within 1q23.1-q24.1 and is approximately $16 \mathrm{~kb}$ in length. This allele, which encodes SLAM family member 7 protein, plays a role in the modulation of natural killer cell activity. 